\title{
Kinetic Analysis of Lead Removal by Natural Hydroxyapatite from Aqueous Solution in High Concentration
}

\author{
Norma Caballero ${ }^{a}$, Pablo Casanova Ozuna ${ }^{\text {, Magna Monteiro }}{ }^{a * 10}$ \\ ${ }^{a}$ Bio and Materials Laboratory, Polytechnic School, National University of Asunción. San Lorenzo, \\ Central, Paraguay.
}

Received: December 12, 2018; Revised: June 6, 2019; Accepted: August 5, 2019

\begin{abstract}
The aim of this work was to study of the kinetic of $\mathrm{Pb}(\mathrm{II})$ sorption, in high lead concentration aqueous solution, by the natural hydroxyapatite (HA) and to verify whether there is a different behavior between natural and synthetic HA under different lead concentrations. Batch experiments were carried out using solutions with high lead concentration, with the objective to evaluate the effect of contact time, HA dosage and initial metal concentration on lead removal. Kinetic data were analyzed by pseudo-first and pseudo-second order models. The sorption data was then correlated with the Langmuir and Freundlich isotherm models. The PZC obtained was slightly different than those reported by other authors, who evaluated the process under low concentrations and synthetic HA as adsorbent. It was possible to identify the optimum relation between $\mathrm{Pb}$ (II) concentrations and mass of HA for efficiency of approximately $100 \%$ at optimum contact time. Although the results show a certain instability during the removal of lead when the concentration is much higher, the process can be considered effective. Liquid samples were analyzed by atomic absorption spectroscopy and solid samples were by X-ray diffraction and Fourier transform infrared spectroscopy.
\end{abstract}

Keywords: Diffusion models, load zero-point, high lead concentration.

\section{Introduction}

Heavy metals are not biodegradable and tend to accumulate in living organisms, causing various diseases and disorders. In particular, lead ion- $\mathrm{Pb}(\mathrm{II})$ has been classified as a hazardous heavy metal with high priority in the context of environmental risk $^{1}$. Further, $\mathrm{Pb}(\mathrm{II})$ is commonly detected in several kinds of wastewaters ${ }^{2-4}$, for example, those produced by industrial processes such as mining, smelting, printing, metal plating, explosive manufacture, leather, and others.

Various methods have been developed to eliminate or reduce heavy metals from wastewaters. In many cases, these methods are very expensive and non-viable, including chemical precipitation, membrane filtration, ion exchange, carbon adsorption and co-precipitation/ adsorption ${ }^{5}$. Recently, many researchers have been studying new methods involving adsorption processes ${ }^{7-9}$. In general, an adsorption processes involve high efficiency materials for heavy metals removal from aqueous solutions, easy handling, availability of different raw materials and low $\operatorname{cost}^{6}$. In the last years, different raw materials ${ }^{10-11}$ have been used as adsorbents for the removal of heavy metals from aqueous media and soil contaminated. Basu et al. ${ }^{12}$ studied the adsorption potential of cucumber peel for lead sorption. The authors reported the optimum parameters to obtain approximately $90 \%$ of metal removal within the first $15 \mathrm{~min}$.
Novais et al. ${ }^{13}$ reported the possibility to apply porous fly ash containing-geopolymer monoliths for lead removal from wastewaters. In this work, authors studied the efficiency of these adsorbent materials using different synthetic lead solutions and confirmed that the removal process is affected by the porosity (max. $78.4 \%$ ) of the sample.

On the other hand, hydroxyapatite (HA) considered a bioceramic material, which has been produced from natural sources and synthesized from high purity precursors for bone implant applications ${ }^{14}$. Its applications in environmental biotechnology areas are increasingly drawing attention of researchers, mainly to eliminate heavy metals and other toxic materials from superficial waters and soil ${ }^{15}$. Most of the work found report the applications of the synthetic $\mathrm{HA}^{2-4 ; 16}$, but few works report the use of natural $\mathrm{HA}^{14-15}$, mainly the HA from bovine bone.

The present study focuses on the removal of $\mathrm{Pb}$ (II) from aqueous solution by hydroxyapatite obtained from bovine bone. The raw material for process this HA is of easy acquisition and its processing does not require high technology or high cost pure precursors. The study includes an evaluation of the effects of various operational parameters, such as contact time, dose of $\mathrm{HA}$, and $\mathrm{pH}$ on the $\mathrm{Pb}$ (II) adsorption process. The adsorption kinetics models and equilibrium isotherm models related with the process were also investigated. The results obtained in this work were compared with the results for synthetic HA found in the literature. 


\section{Materials and Methods}

\subsection{Preparation of lead solutions}

To prepare the stock solution (1000 mg/L), $\mathrm{Pb}\left(\mathrm{NO}_{3}\right)_{2}$ (P.A., Cicarelli, Argentina) was used. The working solutions were prepared by diluting the lead stock solution in different concentrations (100, 200, 400, 600, 1000 and $1400 \mathrm{ppm})$ in appropriate volumes, depending of the assay, by triplicate. The concentration of residual lead ions in the supernatant was determined using an Atomic Absorption Spectrometer (Thermo Scientific iCE 3000). $\mathrm{KNO}_{3}$ (P.A., Anedra), $\mathrm{HNO}_{3}$ (65\% p/p, Anedra) and $\mathrm{NaOH}$ (P.A., Cicarelli, Argentina) were used to adjust the $\mathrm{pH}$. All assays of $\mathrm{Pb}$ (II) removal were studied using the batch adsorption process under stirring at $200 \mathrm{rpm}$, at room temperature.

\subsection{Adsorbent Characterization}

The hydroxyapatite used in this work was obtained from bovine bone and calcined at $900^{\circ} \mathrm{C}$ for $2 \mathrm{~h}$ with heating rate of $10^{\circ} \mathrm{C} / \mathrm{min}$ in air atmosphere, and sieved to obtain a granulometry of $50 \mu \mathrm{m}$. Process methods and characterization results for this adsorbent were previously reported by this workgroup $^{14}$. The HA used presented $\mathrm{Ca} / \mathrm{P}$ ration of 2.00 , approximately; superficial area was $4.106 \mathrm{~m}^{2} / \mathrm{g}$; Acid-basic properties of the HA surface were determined by Point of Zero-Charge $\left(\mathrm{pH}_{\mathrm{PzC}}\right)$ method. For this analysis, $40 \mathrm{~mL}$ of $5 \mathrm{mM}$ $\mathrm{KNO}_{3}$ was added in $1000 \mathrm{ml}$ of $1000 \mathrm{mg} / \mathrm{L} \mathrm{Pb}$ solution. The initial $\mathrm{pH}\left(\mathrm{pH}_{0}\right)$ values of the solutions were roughly adjusted in a range from 3 to 7 by adding either $0.1 \mathrm{~N} \mathrm{HNO}_{3}$ or $\mathrm{KOH}$. $\mathrm{pH}_{0}$ solutions were adjusted and corresponding values were registered before each adjust. HA ( $0.1 \mathrm{~g})$ was added to each flask and the samples were stirred for $24 \mathrm{~h}$. The difference between the initial and final $\mathrm{pH}\left(\mathrm{pH}_{\mathrm{f}}\right)$ values $\left(\Delta \mathrm{pH}=\mathrm{pH}_{0}\right.$ $\mathrm{pH}_{\mathrm{f}}$ ) was plotted against the $\mathrm{pH}_{0}$. The intersection point on the $\mathrm{pH}_{0}$ axis of the resulting curve provides the PZC. The adsorbent sample submitted to $1000 \mathrm{ppm}$ lead solution was characterized by X-ray diffraction, with the objective to verify the possibility of forming the third phase.

\subsection{Batch sorption experiments}

Sorption kinetic and isotherm models of the $\mathrm{HA}$ for $\mathrm{Pb}(\mathrm{II})$ removal were studied. Each one of the batch adsorption assays was carried out by contacting the adsorbent with lead ions solutions. The effect of the contact time was studied using solutions containing $\mathrm{Pb}(\mathrm{II})$ concentrations that varied between $200-1400 \mathrm{mg} / \mathrm{L}$. The amount of HA was kept constant at 1.0 $\mathrm{mg}$. The $\mathrm{pH}$ of the solutions at different initial concentrations was adjusted and the initial $\mathrm{pH}$ used was slightly higher than that of the PZC value obtained in this work. At the end of the assays (24 h), the $\mathrm{pH}$ was recorded for all samples. Plastic bottles were adapted to perform the assays. A series of experiments were also conducted in order to determine the contact time, sorbent dosage and initial ions concentration on the adsorption of $\mathrm{Pb}(\mathrm{II})$. All samples were filtered and the metal ion concentration was determined from filtration. Initial and equilibrium metal concentrations in the aqueous solution was determined using an Atomic Absorption Spectrometer (Thermo Scientific iCE 3000).

The theoretical percentage of lead ions removed by HA during the batch assays was determined using the following equation (1), expressed as:

$$
\text { Removal\% }=\frac{C_{0}-C_{t}}{C_{0}} \times 100,
$$

where $C_{0}$ and $C_{t}$ are the initial and final concentrations $(\mathrm{mg} / \mathrm{L})$ of lead ions in solution, respectively. The $C_{t}$ corresponds to the concentration at time $t$. The adsorption kinetics studies were carried out with known dose of HA (0.56 g) for $200 \mathrm{~mL}$ of the metal ion solution, in different initial concentrations (144, 213 and $224 \mathrm{mg} / \mathrm{L}$ ). Batch adsorption studies were performed with the objective of understanding the mechanism of $\mathrm{Pb}(\mathrm{II})$ ion adsorption on HA by fitting the experimental data to the theoretical models, particularly, Langmuir and Freundlich models.

\section{Discussion and Results}

\subsection{Influence of the $\mathrm{pH}$}

Figure 1 shows the $\mathrm{pH}$ effects considering $\mathrm{Pb}$ initial ions in concentration of $100 \mathrm{mg} / \mathrm{L}$. It is possible to verify the curve $\Delta \mathrm{pH} \times \mathrm{pH}_{0}$, where its intersection with the $x$ axis $\left(\mathrm{pH}_{0}\right)$ provides the PZC value. According to the result, the PZC for bovine HA is 4.78. This means that, at this $\mathrm{pH}$ value, for the conditions applied, the net surface charge is zero and the $\mathrm{H}^{+}$and $\mathrm{OH}^{-}$ions are called potential-determining ions. For the current process, it is foreseen that the species of anionic nature will be adsorbed for a $\mathrm{pH}$ lower than 4.78 , and for higher $\mathrm{pHs}$, the removal of cationic species will be favored ${ }^{16-17}$. Since the lead (III) species is cationic, it is necessary that the surface of the HA particles have anionic characteristic to favor the start of the cationic removal process.

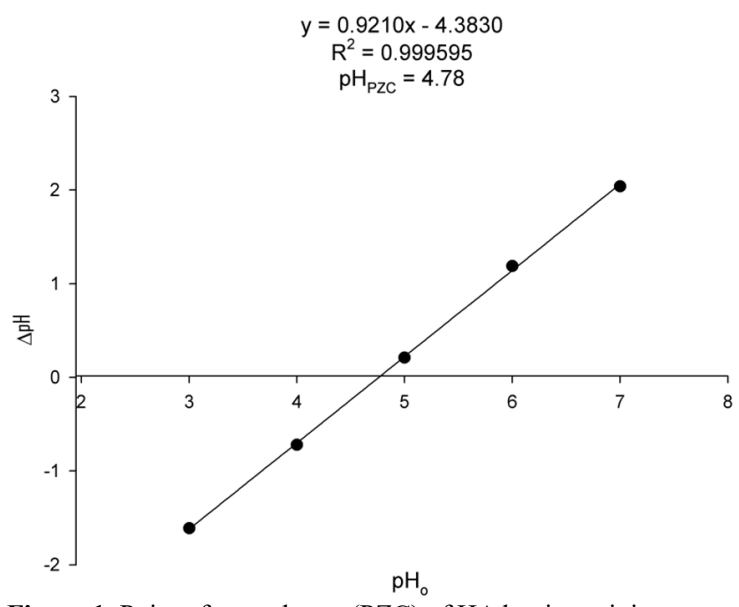

Figure 1. Point of zero charge (PZC) of HA bovine origin. 
For the next assays, a $\mathrm{pH}$ value of 5.44 was used $^{17}$. The point of zero charge indicates the most adequate interval for the $\mathrm{pH}$ value to reach the efficient removal of a certain anionic or cationic contaminant ${ }^{18}$. For example, Ramesh et al. ${ }^{3}$ reported 6.89 as PZC value, for nanoparticulates synthesized hydroxyapatite obtained by precipitation method, and Mousa et al. ${ }^{4}$ found 3.00 as PZC for a nano-hydroxyapatite synthesized by the wet route. According to references and this work, the PZC presents different values for HA of different characteristics, therefore, it is possible that PZC value does not depend only on the quantitative relation between adsorbent/adsorbate. It might probably depend on other parameters such as temperature and agitation time, or other parameters.

\subsection{Effect of contact time and adsorbent characterization}

The non-adjusted $\mathrm{pH}$ of the $\mathrm{Pb}$ solution considering the concentrations of 200 to $1400 \mathrm{ppm}$, did not notoriously variate and presented an average of $4.76 \pm 0.02$. The initial $\mathrm{pH}_{\mathrm{i}}$ was adjusted for each solution at 4.80. In Figure 2, it can be observed that $\Delta \mathrm{pH}$ increases as $\mathrm{Pb}$ concentrations decrease. Possibly, $\Delta \mathrm{pH}$ is related with $\mathrm{HA} / \mathrm{Pb}$ ratio in the solution, i.e. the higher the ratio the greater $\Delta \mathrm{pH}$. It is possible to verify, too, that the percentage removal of $\mathrm{Pb}(\mathrm{II})$ ions is independent on the initial concentration within 24 hours. Ramesh et al. ${ }^{3}$ and Mousa et el. ${ }^{4}$ report similar behavior, even using nano-structured hydroxyapatite as adsorbent. It is true that, for nano-hydroxyapatite, the equilibrium time is smaller, since the surface area has a great influence on the removal of ions, the higher the surface area the greater the contact area, Nevertheless, independently of particle size and other possible parameters that can directly influence on the equilibrium time, the removal was $95 \%$ approximately, or more, in the first hours of removal. After this time elapses, removal becomes slower, which could be associated with the reduction of the active sites number ${ }^{18}$ and/or the consequent increase in $\mathrm{pH}$, leading to the saturation of the process.

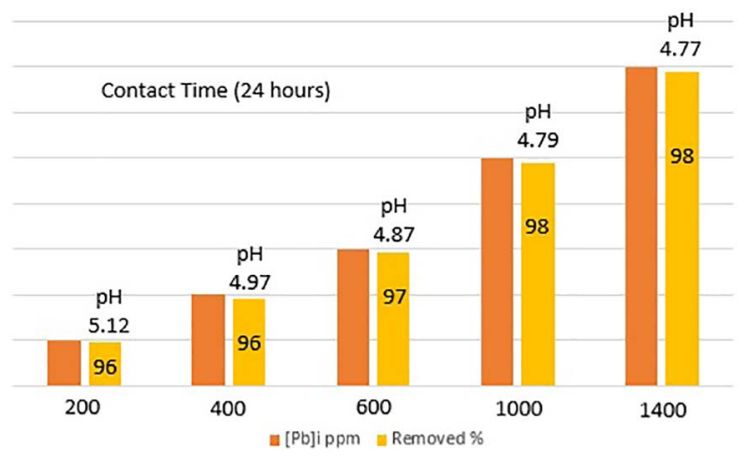

Figure 2. Effect of contact time on the removal of $\mathrm{Pb}$ (II) by adsorption onto HA, at different initial concentration.
In Figure 3, it is possible to visualize the results obtained for each sample, considering different amounts of HA. It is observed that the elimination of lead increases with the increase of HA dose, which means that surface area directly influences the elimination process ${ }^{4}$. We can consider that with mass increase, also increases the amount of available sites for $\mathrm{Ca}-\mathrm{Pb}$ ionic exchange also increases, resulting in a high initial rate of adsorption. The removal percentage of $\mathrm{Pb}$ (II) in aqueous solution by $\mathrm{HA}$ increases rapidly to approximately $100 \%$ for a dose of $0.7 \mathrm{~g}$ of HA for the concentration considered.

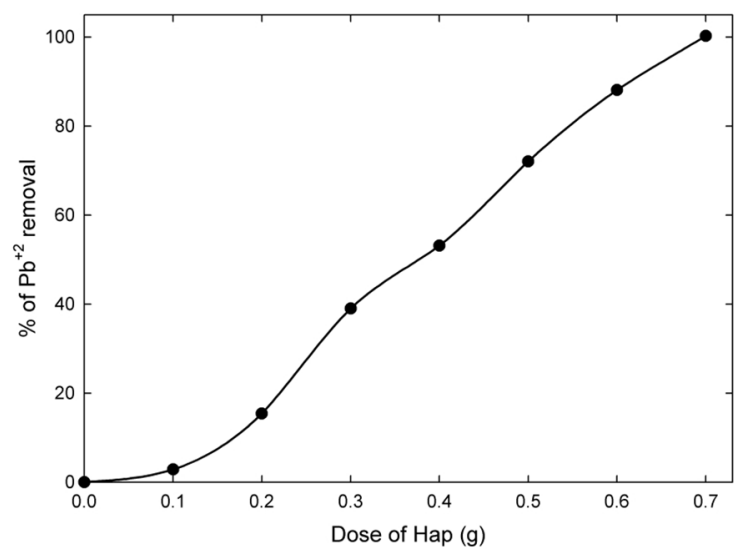

Figure 3. Effect of adsorbent dose on the removal of lead ions by HA.

Figure 4(a) shows FTIR spectrum for different lead concentrations, it is possible to verify the $1385.02 \mathrm{~cm}^{-1}$ band attributed to nitrate group ${ }^{19}$, this band increases with increase of the lead concentration. This could indicate that nitrate has also been incorporated into hydroxyapatite when present at high concentrations. It is also possible to observe the bands 1413.07 and $1458.56 \mathrm{~cm}^{-1}$ attributed to carbonate groups. In concordance with this, it is possible to confirm the possibility of precipitation of the lead carbonate hydroxide phase. Figure 4(b) shows powder diffraction of the natural HA as-processed (red line) and submitted to assay of $1000 \mathrm{ppm}$ of $\mathrm{Pb}$ (II) solution (blue line). In this pattern, it is possible to observe, during the removal of $\mathrm{Pb}(\mathrm{II})$, the precipitation of three phases (ICSD name): hydroxyapatite, lead hydroxyapatite and lead carbonate hydroxide. Precipitation of the two phases of lead, both hydroxyapatite and carboapatite, reveals that calcium ions were replaced by lead, both in the hydroxyapatite and the carboapatite phases $\left(\mathrm{Pb}_{10-\mathrm{x}}\left(\mathrm{PO}_{4} ; \mathrm{CO}_{3}\right)_{3}(\mathrm{OH})\right)$. These crystalline phases were identified and compared with patterns registered in the International Center for Diffraction data (ICDD) powder diffraction files (PDF), 01-089-6440, 01-084-0814 and 00-013-0131, respectively. 


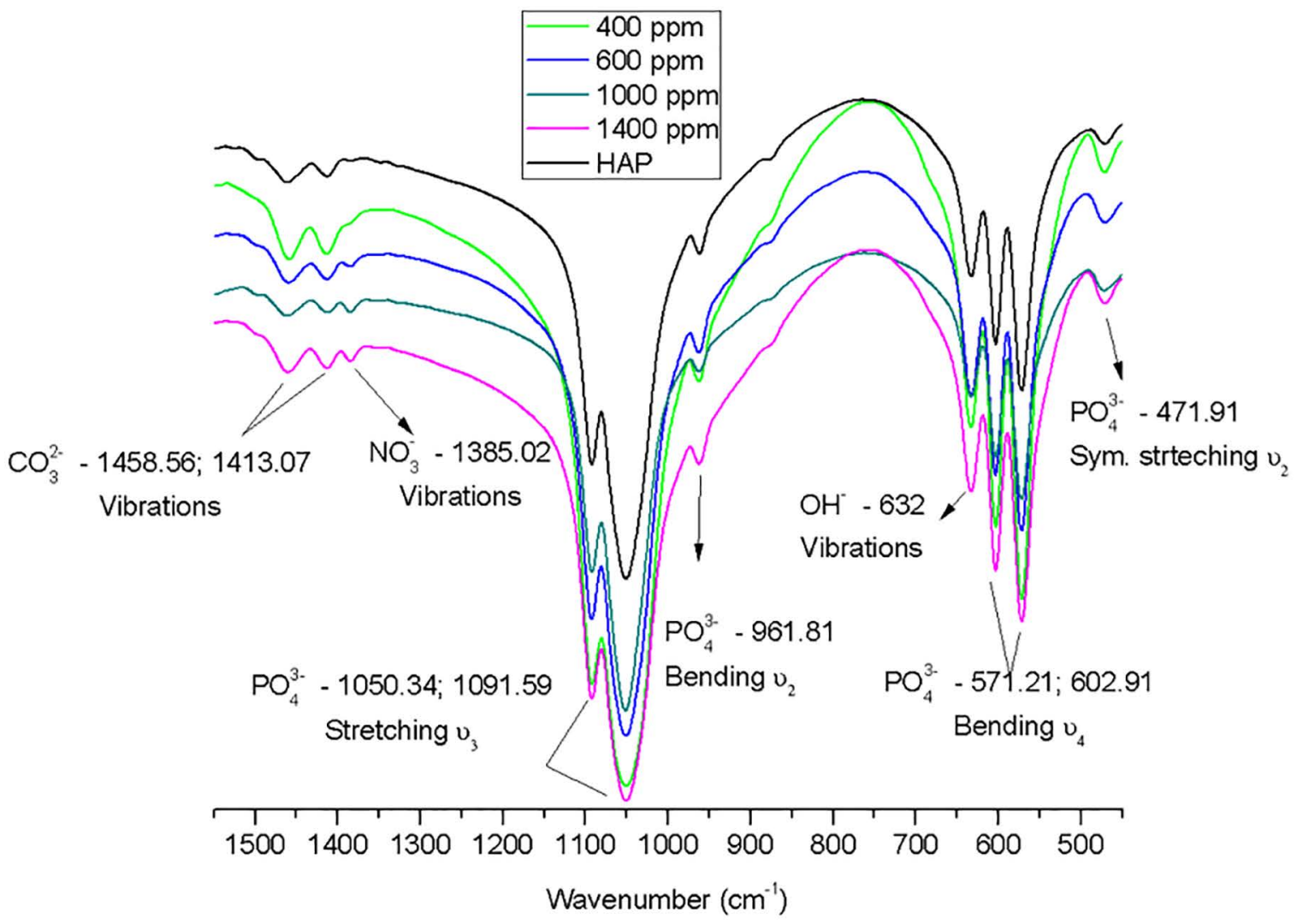

(a)

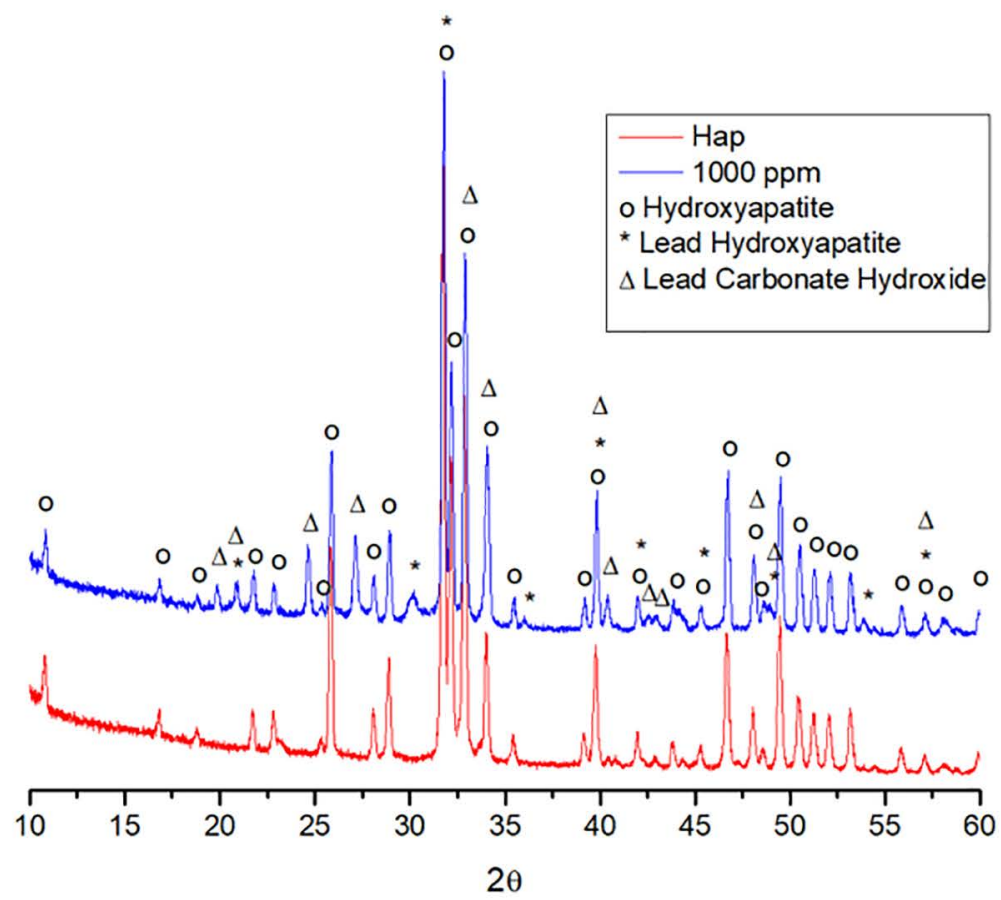

(b)

Figure 4. (a) XRD and (b) FTIR of HAP from bovine bone submitted to assay of $1000 \mathrm{ppm}$ of Pb(II) solution. 


\subsection{Adsorption kinetics}

Various models can be used to determine the adsorption process. Lagergren's model is fre-quently applied to evaluate the experimental data. The sorption kinetics of $\mathrm{Pb}$ (II) in HA was analyzed using Lagergren pseudo-first (eq. 2) and pseudo-second (eq. 3 ) order models ${ }^{20-21}$ :

$$
\begin{aligned}
\log \left(q_{e}-q_{t}\right) & =\log \left(q_{e}\right)-\frac{k_{1}}{2.303} t \\
\left(\frac{t}{q_{t}}\right) & =\frac{l}{k_{2} q_{e}^{2}}+\frac{l}{q_{e}}
\end{aligned}
$$

where $q_{t}$ is the amount of metal ions adsorbed $(\mathrm{mg} / \mathrm{g})$ at time $t$ (min), $q_{e}$ is the amount of metal ions adsorbed $(\mathrm{mg} / \mathrm{g})$ at equilibrium, $k_{1}$ is the pseudo-first order reaction rate constant for adsorption $\left(\mathrm{min}^{-1}\right)$, and $k_{2}$ is the pseudo-second order rate constant $\left(\mathrm{g} /\left(\mathrm{mg} \cdot \mathrm{min}^{-1}\right)\right)$.

The effect of the initial concentration of $\mathrm{Pb}$ (II) on the adsorption kinetics reveals that the adsorption by HA, $q$, increases with the increase of the initial concentration. In Figure 5, the slope of each curve denotes the rate of temporary adsorption $(\mathrm{dq} / \mathrm{dt})$ at each point. When the initial concentration goes from 144 to $213 \mathrm{ppm}$, the adsorption rate decreases with the contact time until it gradually becomes constant. It could be expected that this behavior be maintained as the initial concentration increases; however, the opposite effect occurs, when the concentration goes from 213 to $224 \mathrm{ppm}$, the amount of lead ions adsorbed by the HA decreases. Figure 6 (a) shows that pseudo-first order model failed to provide a realistic estimate of $q_{e}$ for high lead concentrations, too.
The values of the rate parameters and correlation coefficient $R^{2}$ have been obtained and listed in Table 1 .

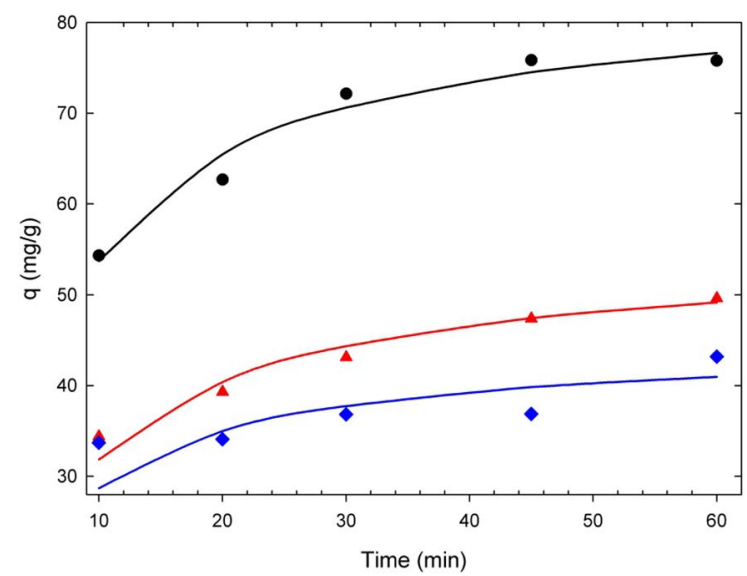

Figure 5. The Adsorption of $\mathrm{Pb}(\mathrm{II})$ at different initial concentration onto HA.

According to (3), the pseudo-second order model is based on the assumption that sorption follows a second order mechanism, so that the sorption rate is proportional to the square of the number of vacant sites.

The plot for $\left(t / q_{t}\right)$ and $t$ should give a linear relationship from which $q_{e}$ and $k_{2}$ can be determined from the slope and interception of the plot, respectively. This led to the determination of the value of second-order rate constant, $k_{2}=(2.9 \pm 0.9) \times 10^{-3}\left(\mathrm{~g} /\left(\mathrm{mg} \cdot \mathrm{min}^{-1}\right)\right)$. The $q_{e}$ value $66.92 \mathrm{mg} / \mathrm{g}$ is close to the experimental one $56.21 \mathrm{mg} / \mathrm{g}$, which indicates this model is appropriate. The $R^{2}$ values are much closer to 1 ,
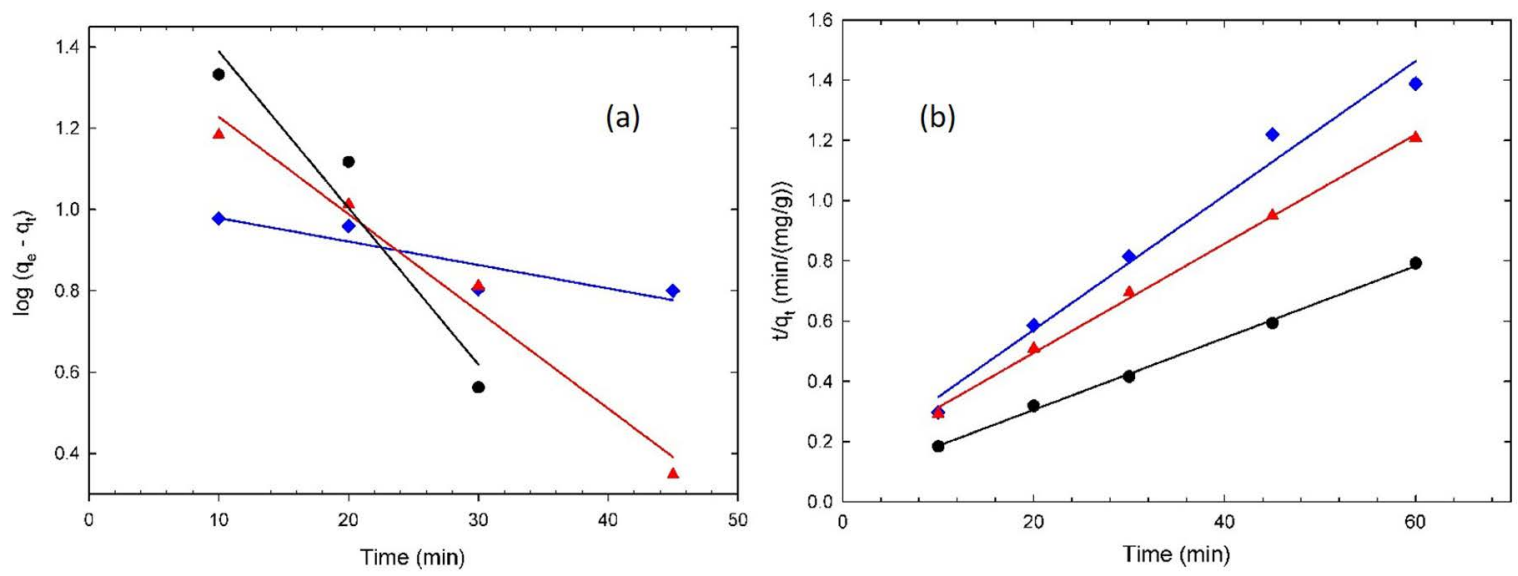

Figure 6. Pseudo (a) -first and (b) -second order plot for $\mathrm{Pb}(\mathrm{II})$ sorption onto HA.

Table 1. Parameter values calculated using the pseudo-first and the pseudo-second order models for the adsorption of $\mathrm{Pb}$ (II) onto $\mathrm{HA}$.

\begin{tabular}{cccccccc}
\hline \multirow{2}{*}{$\mathrm{Pb}(\mathrm{II})$ ions } & \multicolumn{3}{c}{ Pseudo first-order } & \multicolumn{5}{c}{ Pseudo second-order } \\
\cline { 2 - 8 } & $q_{e}$ & $k_{1}$ & $R^{2}$ & $v_{0}$ & $q_{e}$ & $k_{1}$ & $R^{2}$ \\
\hline 144 & 29.3 & $5.51 \times 10^{-3}$ & 0.9786 & 7.56 & 55.2 & $2.48 \times 10^{-3}$ & 0.9977 \\
213 & 59.4 & 0.089 & 0.9389 & 15.0 & 83.8 & $2.13 \times 10^{-3}$ & 0.9980 \\
224 & 10.9 & 0.133 & 0.8018 & 15.2 & 61.8 & $3.98 \times 10^{-3}$ & 0.9786 \\
\hline
\end{tabular}


i.e. the value of the correlation coefficient indicates that de adsorption data fit best the pseudo-second order model. The following expression denotes the initial sorption rate $v_{0}\left(\mathrm{~g} /\left(\mathrm{mg} \cdot \mathrm{min}^{-1}\right)\right)$ :

$$
v_{0}=k_{2} q_{e}^{2}
$$

The initial sorption rate calculated was $12.81\left(\mathrm{~g} /\left(\mathrm{mg} \cdot \mathrm{min}^{-1}\right)\right)$. The results obtained from adsorption kinetics are according to Sangeetha et al. ${ }^{22}$, who worked with high lead concentration, and to Moura et al. ${ }^{4}$ who worked on low lead concentration, where the best model that fixed the behavior is the pseudosecond order, considering both works. Therefore, it is possible to state that the adsorption kinetic is independent of the initial concentrations of lead.

\subsection{Adsorption isotherms}

An adsorption isotherm is a curve that can describe the phenomenon that governs the retention of a substance in aqueous media at a constant temperature and $\mathrm{pH}$, whose physicochemical parameters provide an idea of the mechanism of adsorption, surface properties and the degree of affinity of the adsorbent ${ }^{23-24}$. Langmuir isotherm is one of the isotherms, which assumes an adsorption in monolayer onto surface with a finite number of identified sites, and its linear form can be expressed as:

$$
\frac{C_{e}}{q}=\frac{1}{K q_{\max }}+\frac{C e}{q_{\max }}
$$

where $K(\mathrm{~L} / \mathrm{g})$ is the equilibrium adsorption constant, related to the affinity of the binding sites and $q_{\max }(\mathrm{mg} / \mathrm{g})$ is the maximum amount of lead ions per unit mass of sorbent, considering all binding sites are occupied. The Freundlich isotherm, different from that of Langmuir, describes nonideal and reversible adsorption, not restricted to monolayer formation. This empirical model can be applied to multilayer adsorption, with a non-uniform distribution of adsorption heat and affinities on the heterogeneous surface ${ }^{25}$. In this context, the simplified Freundlich equation is given by:

$$
\log q_{e}=\log K_{f}+\frac{1}{n} \log C_{e},
$$

where $K_{f}$ and $n$ are the Freundlich constants and are related to the adsorption capacity of the sorbent and the adsorption intensity, respectively.

According to results, Table 2, it was observed that the $R^{2}$ obtained by Langmuir model, Fig. 7(a), is higher than that of the Freundlich model, Fig. 7(a), which means that the adsorption assumes the Langmuir characteristics, it is monolayer. The values obtained by Freundlich indicate that conditions for adsorption are not favorable. Ramesh et al. ${ }^{20}$ report that the constant and value lying in the range of 1-10 for single and binary systems confirm the favorable conditions for Langmuir adsorption model, too.

\section{Conclusion}

According to results obtained for the study of the adsorption balance and the kinetics of the $\mathrm{Pb}$ (II) on $\mathrm{HA}$, obtained from bovine bone, we can consider that natural HA exhibits a similar behavior to the synthetic HA reported in the literature, where a high percentage of removal is observed in the first few minutes and then its speed is reduced until a point of saturation. The natural HA proved to be effective for the removal of lead ions in aqueous solution, but presented a different behavior in comparison with low lead concentration solution reported in the literature.

Table 2. Parameter values calculated using the pseudo-first and the pseudo-second order models for the adsorption of $\mathrm{Pb}$ (II) onto $\mathrm{HA}$.

\begin{tabular}{lcccccc}
\hline Metals & \multicolumn{3}{c}{ Langmuir model } & & \multicolumn{2}{c}{ Freundlich model } \\
\hline & $B \mathrm{~L} / \mathrm{g}$ & $Q_{\max } \mathrm{mg} / \mathrm{g}$ & $R^{2}$ & $K_{f}$ & $R^{2}$ \\
$\mathrm{~Pb}$ ions & 1.55 & 89 & 0.99 & 78 & 31.6 \\
\hline
\end{tabular}
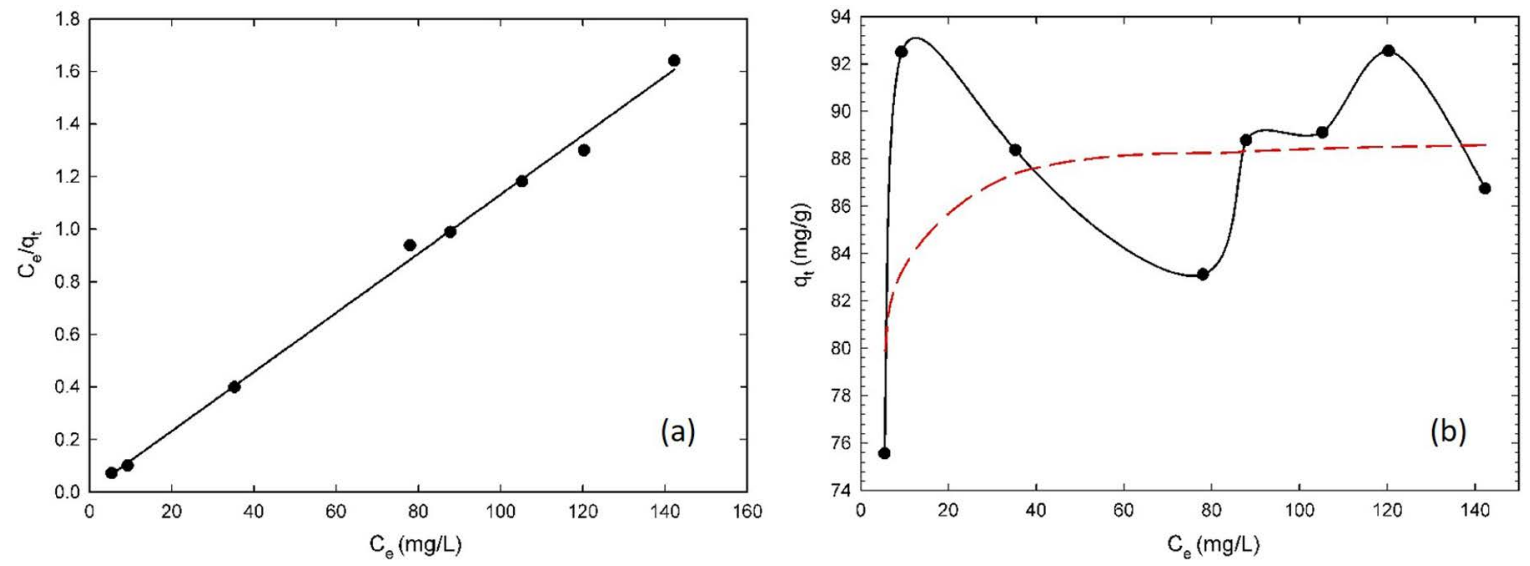

Figure 7. Isotherms plot for sorption of $\mathrm{Pb}$ by natural $\mathrm{HA}$ (a) Langmuir (b) Freundlich models. 
The $\mathrm{pH}_{\mathrm{pzC}}$ presented a value of 4.78 , completely different when compared to the HA synthesized, reported in the literature. In addition, the presence of carbonate in the HA structure verified by the results ofFTIR, can explain the presence of a third phase, lead carbonate hydroxide, identified by XRD. The precipitation of this third phase suggests a more detailed study about the conditions, stability and consequences of this phase. The results indicate that the $\mathrm{Pb}$ (II) adsorption on natural HA can be better described by the pseudo second order model. The Langmuir isotherm was adjusted better than the Freundlich isotherm for the experimental data suggesting an adsorption in monolayer. The optimal dose of HA for the elimination of $\mathrm{Pb}(\mathrm{II})$ is 0.7 $\mathrm{g} / \mathrm{L}$ with removal efficiency of $100 \%$, approximately. After analyzing all the results, it was recorded that the capacity for lead adsorption by native bovine HA was $89 \mathrm{mg} / \mathrm{g}$, approximately.

\section{Acknowledgments}

Authors thank the financial support of CONACYT/ PROCIENCIA/FEEI Paraguay (Proyecto14-INV-267).

\section{References}

1. Volesky B. Detoxification of metal-bearing effluents: biosorption for the next century. Hydrometallurgy. 2001;59(2-3):203-216.

2. Liao D, Zheng W, Li X, Yang Q, Yue X, Guo L, et al. Removal of lead(II) from aqueous solutions using carbonate hydroxyapatite extracted from eggshell waste. Journal of Hazardous Materials. 2010;177(1-3):126-130.

3. Ramesh ST, Rameshbabu N, Gandhimathi R, Srikanth Kumar $\mathrm{M}$, Nidheesh $\mathrm{PV}$. Adsorptive removal of $\mathrm{Pb}$ (II) from aqueous solution using nano-sized hydroxyapatite. Applied Water Science. 2013;3(1):105-113.

4. Mousa SM, Ammar NS, Ibrahim HA. Removal of lead ions using hydroxyapatite nano-material prepared from phosphogypsum waste. Journal of Saudi Chemical Society. 2016;20(3):357-365.

5. Ricordel S, Taha S, Cisse I, Dorange G. Heavy metals removal by adsorption onto peanut husks carbon: characterization, kinetic study and modeling. Separation and Purification Technology. 2001;24(3):389-401.

6. Bulgariu L, Răţoi M, Bulgariu D, Macoveanu M. Equilibrium study of $\mathrm{Pb}$ (II) and $\mathrm{Hg}$ (II) sorption from aqueous solutions by moss peat. Environmental Engineering and Management Journal. 2008;7(5):511-516.

7. Payne KB, Abdel-Fattah TM. Adsorption of Divalent Lead Ions by Zeolites and Activated Carbon: Effects of $\mathrm{pH}$, Temperature, and Ionic Strength. Journal of Environmental Science and Health, Part A - Toxic/Hazardous Substances and Environmental Engineering. 2005;39(9):2275-2291.

8. Leyva R, Flores J, Díaz P, Berber M. Adsorción de Cromo (VI) en Solución Acuosa sobre Fibra de Carbón Activado. Información Tecnológica. 2008;19(5):27-36.

9. Lavado Meza C, Sun Kol MR, Bendezu S. Adsorption of lead from industrial wastewater using activated carbons with $\mathrm{H}_{3} \mathrm{PO}_{4}$. Revista de la Sociedad Química del Perú. 2010;76(2):165-178.
10. Yao ZY, Qi JH, Wang LH. Equilibrium, kinetic and thermodynamic studies on the biosorption of $\mathrm{Cu}(\mathrm{II})$ onto chestnut shell. Journal of Hazardous Materials. 2010;174(1-3):137-143.

11. Tejada Tovar C, Quinonez Bolaños E, Tejeda Benitez L, Marimon Bolivar W. Absorción de Cromo Hexavalente en soluciones acuosas por cascaras de naranja (Citrus sinensis). Producción + Limpia. 2015;10(1):9-21.

12. Basu M, Guha AK, Ray L. Adsorption of Lead on Cucumber Peel. Journal of Cleaner Production. 2017;151:603-615.

13. Novais RM, Buruberri LH, Seabra MP, Labrincha JA. Novel porous fly-ash containing geopolymer monoliths for lead adsorption from wastewaters. Journal of Hazardous Materials. 2016;318:631-640.

14. Ferreiro O, Balestra RM, Ribeiro AA, Oliveira MV, Monteiro M. Removal of lead by hydroxyapatite obtained from bovine bone. In: Congresso Latino Americano de Órgãos Artificiais e Biomateriais - COLAOB; 2012 Aug 22-25, Natal, RN, Brazil.

15. Ferreiro O, Yubero F, Balestra RM, Varella M, Monteiro M. Bovine Bone Processing for Biofilter Application. Materials Science Forum. 2012;727-728;727-730.

16. Baillez S, Nzihou A, Bernache-Assolant D, Champion E, Sharrock P. Removal of aqueous lead ions by hydroxyapatites: Equilibria and kinetic processes. Journal of Hazardous Materials. 2007;139(3):443-446.

17. Amaringo Villa FA, Hormaza Anaguano A. Determination of the point of zero charge and isoelectric point of two agricultural wastes and their application in the removal of colorants. Revista de Investigación Agraria y Ambiental. 2013;4(2):27-36.

18. Ellis DE, Terra J, Warschkow O, Jiang M, González GB, Okasinski JS, et al. A theoretical and experimental study of lead substitution in calcium hydroxyapatite. Physical Chemistry Chemical Physics. 2006;8:967-976.

19. Destainville A, Champion E, Bernache-Assollant D, Laborde E. Synthesis, characterization and thermal behavior of apatitic tricalcium phosphate. Materials Chemistry and Physics. 2003;80(1):269-277.

20. Ho YS, McKay G. Pseudo-second order model for sorption processes. Process Biochemistry. 1999;34(5):451-465.

21. Ramesh ST, Rameshbabu N, Gandhimathi R, Nidheesh PV, Srikanth Kumar M. Kinetics and equilibrium studies for the removal of heavy metals in both single and binary systems using hydroxyapatite. Applied Water Science. 2012;2(3):187-197.

22. Sangeetha K, Vidhya G, Vasugi G, Girija EK. Lead and cadmium removal from single and binary metal ion solution by novel hydroxyapatite/alginate/gelatin nanocomposites. Journal of Environmental Chemical Engineering. 2018;6(1):1118-1126.

23. Limousin G, Gaudet JP, Charlet L, Szenknect S, Barthès V, Krimissa M. Sorption isotherms: A review on physical bases, modeling and measurement. Applied Geochemistry. 2007;22(2):249-275.

24. Bulut E, Özacar M, Şengil IA. Adsorption of malachite green onto bentonite: Equilibrium and kinetic studies and process design. Microporous and Mesoporous Materials. 2008;115(3):234-246.

25. Foo KY, Hameed BH. Insights into the modeling of adsorption isotherm systems. Chemical Engineering Journal. 2010;156(1):2-10. 